\title{
Berberine enhances chemosensitivity to irinotecan in colon cancer via inhibition of NF- $\mathrm{NB}$
}

\author{
MEILING YU ${ }^{1,2^{*}}$, XUHUI TONG ${ }^{2 *}$, BENQUAN QI $^{1,2^{*}}$, HONGDANG QU ${ }^{1,2}$, SHUYING DONG $^{2}$, \\ BINBIN YU ${ }^{2}$, NAIJU ZHANG ${ }^{1,2}$, NAN TANG ${ }^{3}$, LINGZHI WANG ${ }^{4}$ and CUILING ZHANG ${ }^{2}$ \\ ${ }^{1}$ Department of Pharmacy, The First Affiliated Hospital of Bengbu Medical College, Anhui, Bengbu 233004; \\ ${ }^{2}$ Faculty of Pharmacy, Bengbu Medical College, Anhui, Bengbu 233030; ${ }^{3}$ Department of Pharmacy, \\ Guangdong Medical College, Dongguan, Guangdong 523808; ${ }^{4}$ Department of Anaesthesia, \\ The Second Affiliated Hospital, Guangzhou Medical University, Guangzhou 510260, P.R. China
}

Received April 1, 2013; Accepted October 17, 2013

DOI: $10.3892 / \mathrm{mmr} .2013 .1762$

\begin{abstract}
Previous studies have shown that irinotecan (CPT-11) impairs chemotherapy-induced apoptosis by activating nuclear factor $-\kappa \mathrm{B}(\mathrm{NF}-\kappa \mathrm{B})$ and a number of strategies have been employed to augment chemosensitivity through the suppression of NF- $\mathrm{kB}$ activation. Berberine, a botanical alkaloid, was reported to enhance chemosensitivity to 5-fluorouracil and doxorubicin by suppressing NF- $\mathrm{KB}$ activation. In the present study, the effect of berberine on CPT-11-induced apoptosis was investigated through the inhibition of NF- $\mathrm{KB}$. Inhibition of NF- $\mathrm{kB}$ activation by $\mathrm{p} 65$ small interfering RNA was shown to potentiate apoptosis induced by CPT-11. Berberine suppressed CPT-11-induced NF- $\mathrm{KB}$ activation in a dose-dependent manner and enhanced chemosensitivity to CPT-11 by downregulating NF- $\kappa \mathrm{B}$ activation of antiapoptotic genes, c-IAP1, c-IAP2, survivin and $\mathrm{Bcl}-\mathrm{xL}$. The current observations indicate that berberine inhibits NF- $\mathrm{\kappa B}$ activation and may be used to enhance CPT-11-induced apoptosis in colon cancer.
\end{abstract}

\section{Introduction}

Chemotherapy remains an important approach for cancer therapy. However, development of drug resistance during chemotherapy constitutes a predominant challenge in cancer treatment (1). A previous study demonstrated that nuclear factor $-\kappa \mathrm{B}(\mathrm{NF}-\kappa \mathrm{B})$ activation is one mechanism by which tumors become resistant to chemotherapeutic agents (2).

The NF- $\mathrm{BB}$ family contains five members: c-Rel, RelA (p65), RelB, p50 and p52. In its inactive state, NF-kB resides in the cytoplasm due to inhibitory binding by the IкBa

Correspondence to: Dr Cuiling Zhang, Faculty of Pharmacy, Bengbu Medical College, 2600 Donghai Road, Bengbu, Anhui 233030, P.R. China

E-mail: cuilingzhang409@sohu.com

*Contributed equally

Key words: irinotecan, nuclear factor- $\kappa \mathrm{B}$, berberine, apoptosis protein. Upon activation, IкBa undergoes phosphorylation and ubiquitination-dependent degradation, leading to p65 nuclear translocation and binding to a specific consensus sequence in the DNA, which then activates transcription of target genes. Previous studies have shown that NF- $\mathrm{BB}$ may be activated by anticancer chemotherapeutic compounds in a number of cancer cell lines (3-5) and activation of NF- $\kappa \mathrm{B}$ attenuates apoptosis by regulating inhibitors of apoptosis, including c-IAP1, c-IAP2, TRAF1, TRAF2, survivin and Bcl-xL (5-7). Thus, a number of strategies have been employed to enhance apoptosis induced by chemotherapeutic compounds via NF- $\mathrm{B}$ inhibition.

Irinotecan (CPT-11) and its more active metabolite, SN38, are topoisomerase I inhibitors that are efficacious in the treatment of specific neoplasms, including colorectal cancer (8). CPT-11 treatment has been shown to lead to the activation of $\mathrm{NF}-\kappa \mathrm{B}$ in a variety of human colorectal cancer cell lines (7). Several methods of inhibiting $N F-\kappa B$ activation, including antisense oligonucleotides, proteasome inhibitors and p65 small interfering RNA (siRNA) have been shown to reverse inducible chemotherapy resistance to CPT-11 (9-13).

Berberine, a botanical alkaloid derived from a plant that is used traditionally in Chinese medicine, has been reported to exhibit multiple biological and pharmacological properties. Berberine has potential as a chemotherapy adjuvant due to its low toxicity and anticancer properties (14). A previous study demonstrated that berberine potentiates apoptosis induced by 5 -fluorouracil (5-FU) and doxorubicin through suppression of NF- $\kappa \mathrm{B}$ activation (15). However, the effect of berberine on CPT-11-induced apoptosis and the underlying mechanisms have not been investigated. In the present study, berberine was observed to suppress CPT-11-induced NF- $\kappa \mathrm{B}$ activation in a dose-dependent manner and significantly enhanced the sensitization of HCT116 cells to CPT-11-induced apoptosis by downregulating the NF- $\kappa \mathrm{B}$ target antiapoptotic genes, c-IAP1, c-IAP2, survivin and Bcl-xL. These results indicate that berberine enhances chemosensitivity to CPT-11 through the inhibition of NF- $\mathrm{NB}$ activation.

\section{Materials and methods}

Materials. CPT-11, berberine, sulforhodamine B (SRB), trichloroacetic acid (TCA), acetic acid, tumor necrosis factor 
(TNF)- $\alpha$, anti- $\beta$-actin and dimethylsulfoxide (DMSO) were obtained from Sigma-Aldrich (St. Louis, MO, USA). TRIzol and cell culture reagents were purchased from Invitrogen Life Technologies (Carlsbad, CA, USA). Antibodies against p65, c-IAP1, c-IAP2, survivin and Bcl-xL were obtained from Cell Signaling Technology, Inc. (Danvers, MA, USA). Secondary antibodies for western blotting were obtained from Amersham Biosciences Biotech. (Piscataway, NJ, USA). All other reagents were obtained from Sigma-Aldrich unless stated otherwise.

Transfection of siRNA. Human colon cancer HCT 116 cells were obtained from ATCC (Manassas, VA, USA) and were seeded at $2 \times 10^{5}$ cells $/ \mathrm{ml}$ in 6 -well. Cells plates were grown to $50 \%$ confluency and transfected with double-stranded siRNA for NF- $\mathrm{kB}$ p 65 target sequence (sense: 5'-CUUCCAAGUUCCUAUAGAAdTdT-3' and antisense: 3'-dTdTGAAGGUUCAAGGAUAUCUU-5') or with a siRNA nonspecific control (Guangzhou Ribobio Co. Ltd., Guangzhou, China). Silencing was confirmed by the electrophoretic mobility shift assay (EMSA) and western blotting.

SRB assay. Cytotoxicity was determined by the SRB assay as described previously (16). Cells were seeded into 96-well plates and exposed to various concentrations of berberine with or without CPT-11. Following 48-h incubation, cells were fixed with TCA for $1 \mathrm{~h}$ at $4^{\circ} \mathrm{C}$, air-dried and stained with $0.4 \%$ SRB solution for $30 \mathrm{~min}$ at room temperature. Following staining, the SRB solution was removed and cells were subsequently washed with $1 \%$ acetic acid five times. Tris base solution $(10 \mathrm{mM}$; pH 10.5) was used to dissolve the protein-bound dye and the plate was agitated on a plate shaker (Nangjing Changxiang Co. Ltd., Nangjing, China) for $10 \mathrm{~min}$. The $\mathrm{OD}_{570}$ was determined using a 96-well plate reader (MRX; Dynex Technologies, Chantilly, VA, USA).

Western blotting. HCT116 cells were seeded into 6-well plates and exposed to the indicated concentrations of berberine with or without CPT-11. Following treatment, cells were harvested using lysis buffer [20 mM Tris-HCl (pH 7.4), $150 \mathrm{mM} \mathrm{NaCl}$, 1 mM EDTA, 1 mM EGTA, $1 \%$ Triton X-100, 2.5 mM sodium pyrophosphate, $1 \mathrm{mM} \mathrm{Na}_{3} \mathrm{VO}_{4}, 1 \mathrm{mM} \beta$-glycerophosphate and 1:1,000 protease inhibitors]. Protein concentrations were determined by the bicinchoninic acid method. Total protein $(25 \mu \mathrm{g})$ was separated using $8-12 \%$ sodium dodecyl sulfate-polyacrylamide gels and transferred to nitrocellulose blotting membranes. Monoclonal antibodies against p65 $(1: 2,000)$, c-IAP1 $(1: 500)$, c-IAP2 $(1: 500)$ or $\beta$-actin $(1: 8,000)$ were used. Immunopositive bands were visualized using the Amersham ECL ${ }^{\mathrm{TM}}$ Plus Western Blotting Detection kit (GE Healthcare, Piscataway, NJ, USA).

EMSA. EMSA was performed as previously described $(17,18)$. Biotin 3' end-labeled DNA probes containing the NF- $\mathrm{KB}$ consensus site, 3'-TCAACTCCCCTGAAAGGGTCCG-5' and 5'-AGTTGAGGGGACTTTCCCAGGC-3', were purchased from Invitrogen Life Technologies. EMSA was performed using the LightShift Chemiluminescent EMSA kit (Pierce, Rockford, IL, USA). NF- $x$ B activation induced by TNF- $\alpha$ is considered as a positive control. Cells were treated with
$20 \mathrm{ng} / \mathrm{ml} \mathrm{TNF}-\alpha$ for $30 \mathrm{~min}$, TNF- $\alpha$ for $30 \mathrm{~min}$ plus $100 \mathrm{X}$ unlabeled NF- $\kappa \mathrm{B}$ probes or cells were exposed to unlabeled NF- $\mathrm{KB}$ probes. Briefly, the nuclear proteins were incubated in $1 \mathrm{X}$ binding buffer, $50 \mathrm{ng} / \mu 1$ poly (dI-dC), $0.05 \%$ NP- $40,5 \mathrm{mM}$ $\mathrm{MgCl}_{2}, 50 \mathrm{mM} \mathrm{KCl}, 2.5 \%$ glycerol and $\mathrm{ddH}_{2} \mathrm{O}$ for $20 \mathrm{~min}$ at room temperature in a total volume of $20 \mu \mathrm{l}$. The reaction mixture was separated in a $6 \%$ nondenaturing polyacrylamide gel and transferred to a positively charged nylon membrane. The membrane was cross-linked and the biotin-labeled DNA was detected by chemiluminescence.

Hoechst 33258 staining. Hoescht 33258 staining was performed as previously described (19). Cells were treated with different concentrations of berberine $(2.5-10 \mu \mathrm{M})$ for $48 \mathrm{~h}$ with or without $20 \mu \mathrm{M}$ CPT-11 for $24 \mathrm{~h}$ and the cells were fixed with fixation fluid and washed with phosphate-buffered saline (PBS). Subsequently, Hoechst 33258 was used to stain the cells for $5 \mathrm{~min}$ and the cells were then washed with PBS three times. Cell apoptosis was observed by fluorescent microscopy (Olympus, Tokyo, Japan).

Assessment of apoptotic and necrotic cell death. Apoptotic and necrotic cell death was assessed as previously described $(20,21)$. The effect of berberine on CPT-11-induced apoptosis was evaluated by Annexin V/propidium iodide (PI) double staining and flow cytometry. HCT-116 cells were incubated with $10 \mu \mathrm{M}$ berberine for $48 \mathrm{~h}$ and/or $20 \mu \mathrm{M} \mathrm{CPT}-11$ for $24 \mathrm{~h}$. Cells were harvested and resuspended in binding buffer [10 Mm HEPES (pH 7.4), $150 \mathrm{mM} \mathrm{NaCl}, 5 \mathrm{mM} \mathrm{KCl}, 1 \mathrm{mM}$ $\mathrm{MgCl}_{2}$ and $1.8 \mathrm{mM} \mathrm{CaCl}_{2}$ ) followed by Annexin V-flurescein isothiocyanate (FITC) and PI. The percentages of viable, early apoptotic, late apoptotic and necrotic cells were analyzed with a FACScan flow cytometer (Becton Dickinson, San Jose, CA, USA).

Statistical analysis. Statistical analysis between groups was performed by unpaired Student's t-test with SigmaPlot 10.0 software (Systat Software, Inc., San Jose, CA, USA). Data are presented as the mean \pm SEM. $\mathrm{P}<0.05$ was considered to indicate a statistically significant difference.

\section{Results}

Effects of CPT-11 on cell viability in HCT116 cells. The SRB assay was used to detect the cytotoxic effects of CPT-11 in the HCT116 colon cancer cell line. Cells were treated with CPT-11 for $24 \mathrm{~h}$ at concentrations of 5, 10, 20, $40 \mu \mathrm{M}$. Fig. 1 shows that CPT-11 did not affect the viability of HCT116 cells below $40 \mu \mathrm{M}$.

Inhibition of $N F-\kappa B$ activation enhances chemosensitivity to CPT-11 in HCT116 cells. It has been shown that inducible resistance to CPT-11 may be reversed by inhibiting NF-кB (9-13). To confirm this effect, p65 siRNA was used in the present study. HCT116 cells were transfected with p65 siRNA for $48 \mathrm{~h}$, followed by treatment with $20 \mu \mathrm{M}$ CPT-11 for $2 \mathrm{~h}$. Western blot analysis confirmed that the expression of p 65 was reduced in cells treated with p65 siRNA relative to their untreated counterparts and siRNA negative controls (Fig. 2A). Consistent with the downregulation of p65 expression, NF- $\mathrm{kB}$ 


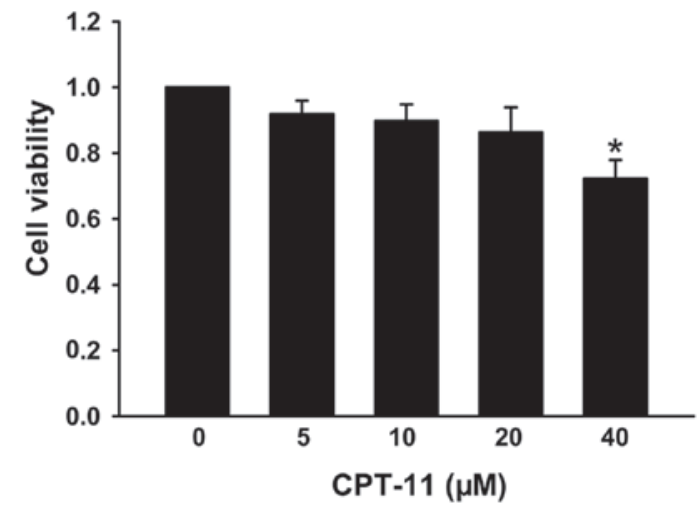

Figure 1. Effect of CPT-11 on cell viability in HCT116 cells. Cells were treated with various concentrations of CPT-11 $(5-40 \mu \mathrm{M})$ for $24 \mathrm{~h}$ and the SRB assay was used to observe cell viability $\left(n=4 ;{ }^{*} \mathrm{P}<0.05\right.$, vs. control cells not exposed to CPT-11). CPT-11, irinotecan; SRB, sulforhodamine B.

A

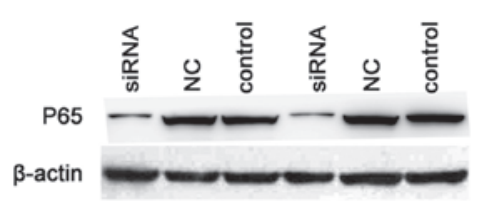

B
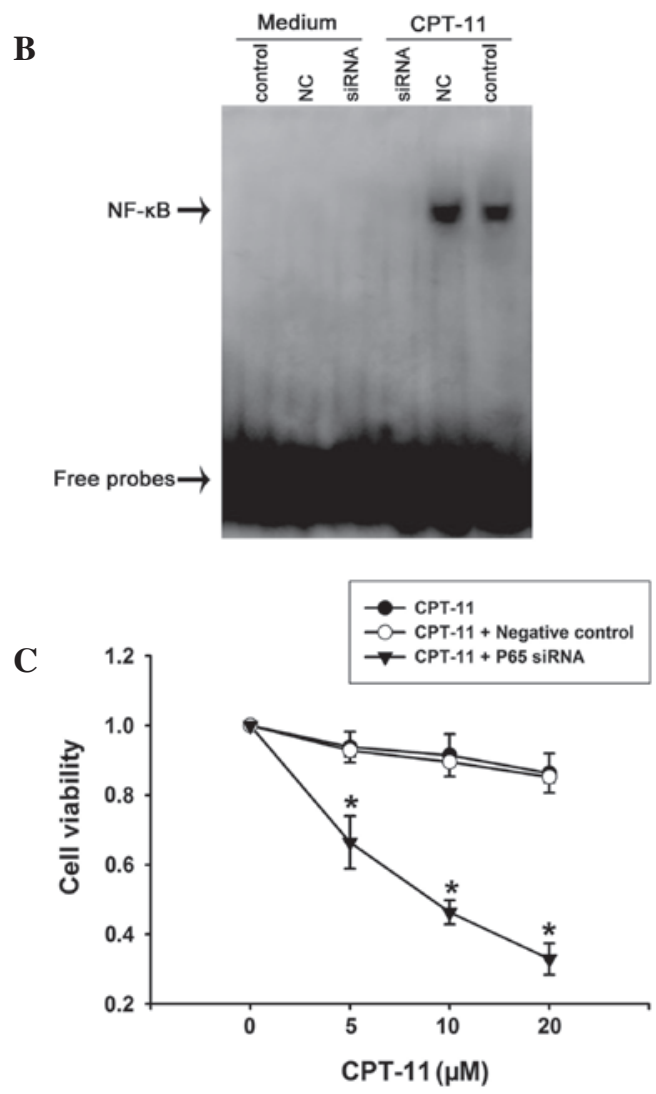

Figure 2. p65 siRNA enhances chemosensitivity to CPT-11 in HCT116 cells. Cells were transfected with p65 siRNA (siRNA, $100 \mathrm{nM}$ ) or an NC (100 nM) for $48 \mathrm{~h}$, followed by treatment with $20 \mu \mathrm{M} \mathrm{CPT}-11$ for $2 \mathrm{~h}$. (A) Western blot analysis was used to detect the effect of p65 siRNA on NF-kB p65 expression. (B) Nuclear extracts were analyzed for NF- $\mathrm{KB}$ activation by EMSA (C) p65 siRNA enhanced chemosensitivity to CPT-11. Cells were transfected with p65 siRNA for $48 \mathrm{~h}$ and then exposed to CPT-11 $(5-20 \mu \mathrm{M})$ for $24 \mathrm{~h}$. Cell viability was observed by the SRB assay $\left(n=4 ;{ }^{*} \mathrm{P}<0.05\right.$, vs. CPT- $11+$ negative control group). siRNA, small interfering RNA; CPT-11, irinotecan; NC,

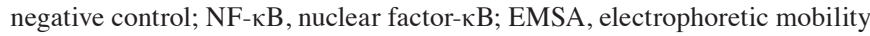
shift assay; .SRB, sulforhodamine B. activation was shown by EMSA to be significantly inhibited by the siRNAs (Fig. 2B).

To address whether the inhibition of $N F-\kappa B$ enhances chemosensitivity to CPT-11 in HCT116 cells, the effect of p65 siRNA on cell viability of CPT-11-treated cells was determined. Following 48-h transfection with p65 siRNA, HCT116 cells were incubated with CPT-11 (5-20 $\mu \mathrm{M})$ for $24 \mathrm{~h}$. The siRNA studies showed that p65 siRNA suppresses CPT-11-induced NF- $\kappa \mathrm{B}$ activation and enhances the chemosensitivity to CPT-11 in HCT116 cells (Fig. 2C). This is in agreement with the hypothesis that inducible resistance to CPT-11 may be reversed by inhibition of NF- $\kappa$ B.

Berberine enhances chemosensitivity to CPT-11 in HCT116 cells. The results in Fig. 2 confirmed that the inhibition of $\mathrm{NF}-\kappa \mathrm{B}$ reverses inducible resistance to CPT-11. Berberine has been reported to inhibit $\mathrm{NF}-\kappa \mathrm{B}$ activation in several cell lines (15). Thus, the effect of berberine on the cytotoxicity of CPT-11 in HCT116 cells was investigated.

The effect of berberine on the cell viability in HCT116 cells was observed. Fig. 3A shows that berberine had no effect on cell viability up to a concentration of $20 \mu \mathrm{M}$; thus, the non-cytotoxic concentrations of berberine, between 2.5 and $10 \mu \mathrm{M}$ were used in the subsequent expriments. To observe the effect of berberine on the cytotoxicity of CPT-11 cells, cells were incubated with berberine $(2.5-10 \mu \mathrm{M})$ for $48 \mathrm{~h}$, followed by incubation with $20 \mu \mathrm{M}$ CPT-11 for $24 \mathrm{~h}$. The results in Fig. 3B demonstrated that the chemosensitivity to CPT-11 was enhanced by berberine, leading to a significant increase in the inhibition rate from $11.42 \pm 2.3 \%$ (20 $\mu \mathrm{M}$ CPT-11 alone) to $49.06 \pm 3.8 \%$ (10 $\mu \mathrm{M}$ berberine plus $20 \mu \mathrm{M}$ CPT-11). Cell apoptosis was detected using Hoechst 33258 and Annexin V/PI staining and the results were consistent with the SRB assay. As shown in Fig. 3C, combination treatment of berberine and CPT-11 in HCT116 cells resulted in an increased number of cells with condensed and fragmented nuclei than CPT-11 or berberine treatment alone. Similar results were confirmed by Annexin V/PI staining (Fig. 3D). These results indicate that berberine enhances the sensitization of HCT116 cells to CPT-11-induced apoptosis.

Berberine inhibits $N F-\kappa B$ activation induced by CPT-11. Previous studies have shown that the NF- $\mathrm{B}$ pathway is activated in HCT116 cells in response to CPT-11 treatment (7) and that colon cancer cells become more sensitive to CPT-11 by abrogating this activation (9-13). Thus, the results in Fig. 3 indicated that berberine may enhance the cytotoxicity of CPT-11 through the suppression of $\mathrm{NF}-\kappa \mathrm{B}$ activation. EMSA was used to determine the effect of berberine on CPT-11-induced NF- $\kappa \mathrm{B}$ activation. HCT116 cells were pretreated with varying concentrations of berberine $(2.5-10 \mu \mathrm{M})$ for $48 \mathrm{~h}$ and exposed to $20 \mu \mathrm{M}$ CPT-11 for 2 h. Fig. 4 shows that berberine alone had no effect on NF- $\kappa \mathrm{B}$ activation, but it suppressed CPT-11-induced $\mathrm{NF}-\kappa \mathrm{B}$ activation in a dose-dependent manner in HCT116 cells. These results indicate that berberine effectively blocks the activation of NF- $\kappa \mathrm{B}$ induced by exposure to CPT-11 and enhances chemosensitivity to CPT-11 in HCT116 cells.

Berberine decreases $c-I A P 1, c-I A P 2$, survivin and $B c l-x L$ expression induced by $C P T-11$. As NF- $\mathrm{B}$ regulates antiapop- 
A

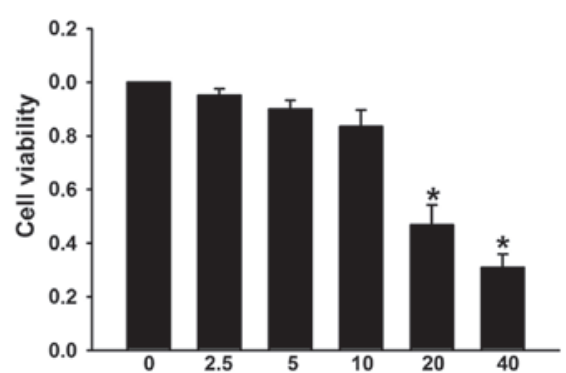

B

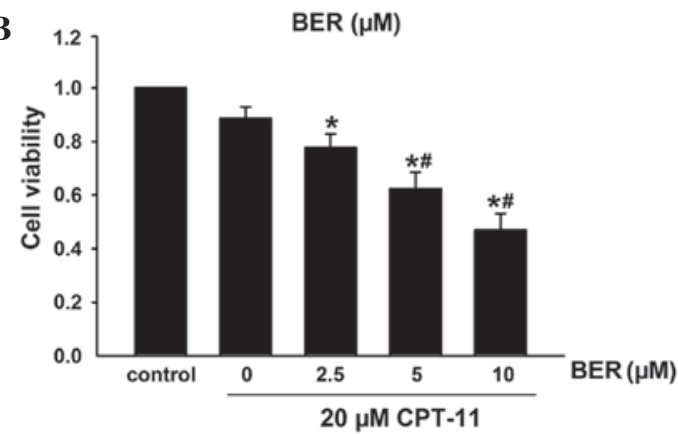

C

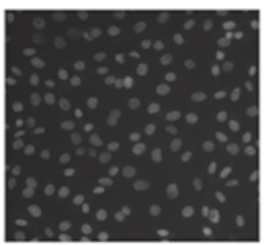

control

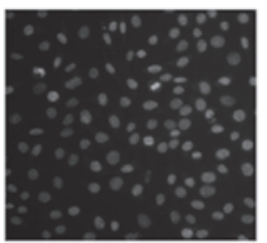

CPT-11

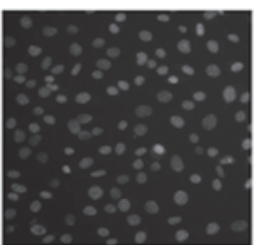

$10 \mu \mathrm{M}$ BER

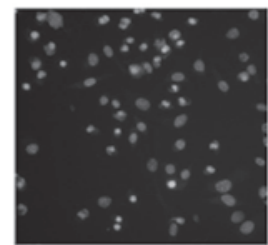

$10 \mu \mathrm{M}$ BER

+ CPT-11

D

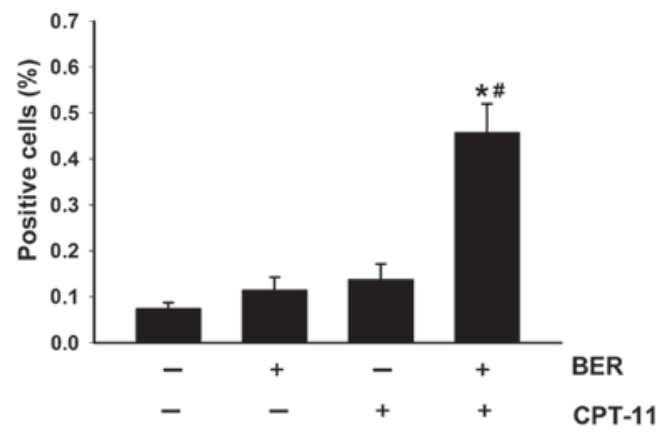

Figure 3. BER enhances chemosensitivity to CPT-11 in HCT116 cells. (A) Effect of berberine on cell viability in HCT116 cells. Cells were treated with various concentrations of BER $(2.5-40 \mu \mathrm{M})$ for $48 \mathrm{~h}$ and the cell viability was detected by an SRB assay ( $\mathrm{n}=5$; ${ }^{*} \mathrm{P}<0.05$, vs. control cells not exposed to berberine). (B) Cells were pretreated with BER $(2.5-10 \mu \mathrm{M})$ for $48 \mathrm{~h}$ and then exposed to $20 \mu \mathrm{M} \mathrm{CPT}-11$ for $24 \mathrm{~h}$. The SRB assay was used to observe cell viability (n=5; ${ }^{*} \mathrm{P}<0.05$, vs. control group; ${ }^{*} \mathrm{P}<0.05$, vs. CPT- 11 group). (C and D) Cells were incubated with $10 \mu \mathrm{M}$ BER for $48 \mathrm{~h}$, followed by incubation with $20 \mu \mathrm{M}$ CPT-11 for $24 \mathrm{~h}$. Apoptosis was detected by Hoechst 33258 and Annexin V/propidium iodide staining ( $\mathrm{n}=3$; ${ }^{*} \mathrm{P}<0.05$, vs. cells not exposed to drugs; ${ }^{*} \mathrm{P}<0.05$ vs. CPT-11 group). BER, berberine; CPT-11, irinotecan; SRB, sulforhodamine B.

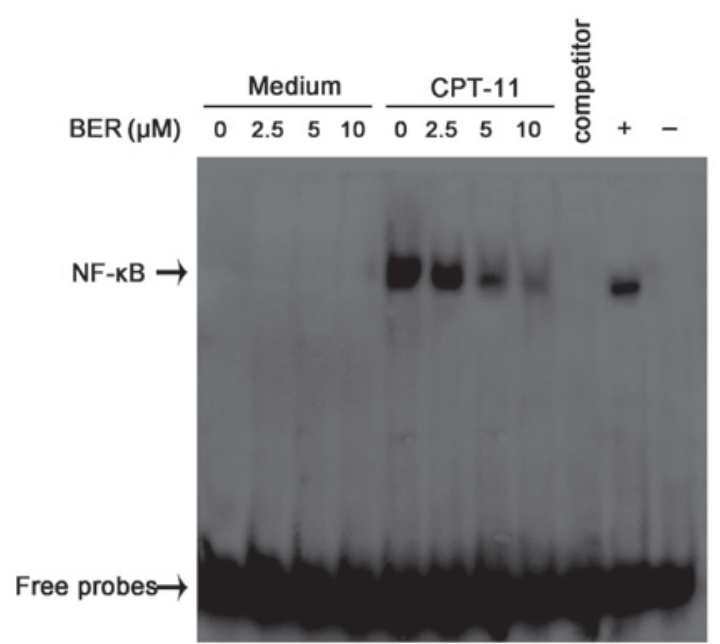

Figure 4. BER suppresses CPT-11-induced NF- $\mathrm{kB}$ activation. HCT116 cells were pretreated with BER $(2.5-10 \mu \mathrm{M})$ for $48 \mathrm{~h}$ and exposed to $20 \mu \mathrm{M}$ CPT-11 for $2 \mathrm{~h}$. Nuclear extracts were assayed for NF- $\mathrm{kB}$ activation by EMSA. NF- $\kappa B$ activation induced by TNF- $\alpha$ is considered as a positive control. Cells were treated with $20 \mathrm{ng} / \mathrm{ml} \mathrm{TNF}-\alpha$ for $30 \mathrm{~min}$ (lane + ) or TNF- $\alpha$ for $30 \mathrm{~min}$ plus 100X unlabeled NF- $\mathrm{KB}$ probes (lane competitor) or cells were exposed to unlabeled NF- $\mathrm{KB}$ probes (lane -). BER, berberine; CPT-11, irinotecan; $\mathrm{NF}-\kappa \mathrm{B}$, nuclear factor- $\kappa \mathrm{B}$; EMSA, electrophoretic mobility shift assay; TNF- $\alpha$, tumor necrosis factor- $\alpha$.

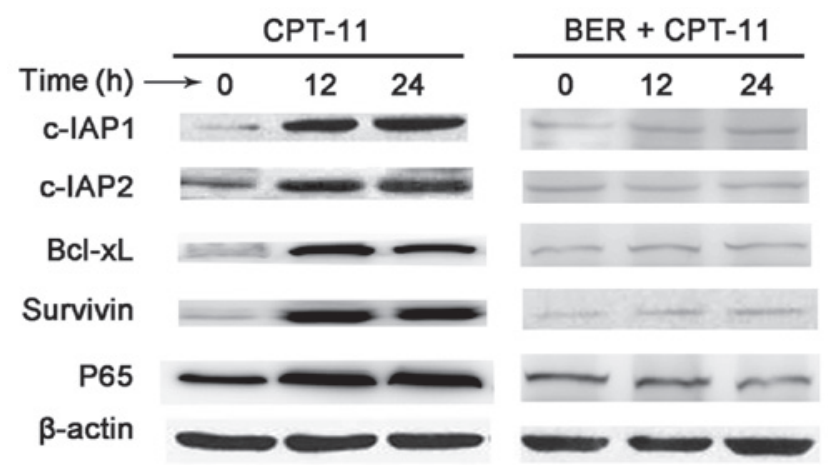

Figure 5. BER treatment decreased c-IAP1, c-IAP2, survivin and Bcl-xL expression induced by CPT-11. Cells were exposed to CPT-11 $(20 \mu \mathrm{M})$ for 12 or $24 \mathrm{~h}$ and pretreated with or without berberine (BER, $10 \mu \mathrm{M}$ ) for $48 \mathrm{~h}$. The expression levels of c-IAP1, c-IAP2, survivin, Bcl-xL and P65 were determined by western blotting. BER, berberine; CPT-11, irinotecan.

totic proteins, including c-IAP1, c-IAP2, survivin and Bcl-xL, the effect of berberine on CPT-11-induced expression of these antiapoptotic proteins was observed. CPT-11 was observed to induce the expression of the antiapoptotic proteins c-IAP1, c-IAP2, survivin and Bcl-xL (Fig. 5) and berberine treatment 
blocked the expression of these proteins. This result indicates that berberine increases the cytotoxicity of CPT-11 by downregulating $\mathrm{NF}-\kappa \mathrm{B}$ target of antiapoptotic genes.

\section{Discussion}

Consistent with previous studies, the results of the current study showed that berberine enhances chemosensitivity to CPT-11 in HCT116 cells by inhibiting NF- $\kappa$ B activation. Berberine suppressed CPT-11-mediated NF- $\kappa$ B activation in a dose-dependent manner and potentiated CPT-11-induced apoptosis by downregulating $\mathrm{NF}-\kappa \mathrm{B}$ antiapoptotic target genes.

CPT-11 is widely used to treat certain neoplasms, including colorectal cancer. However, CPT-11 has been reported to lead to the activation of $\mathrm{NF}-\kappa \mathrm{B}$ in a variety of human colorectal cancer cell lines (7). When activated, $N F-\kappa B$ increases the expression of antiapoptotic genes, which promote cell survival and block apoptosis. In addition, colorectal cancer cells tend to be resistant to CPT-11 (5-7). A number of strategies of NF- $\kappa \mathrm{B}$ inhibition, including antisense oligonucleotides, proteasome inhibitors and p65 siRNA, have been shown as promising approaches for enhancing CPT-11-induced apoptosis (9-13). In the present study, inhibition of NF- $\kappa$ B by p65 siRNA transfection was confirmed to significantly enhance chemosensitivity to CPT-11 in HCT116 cells. In addition, to the best of our knowledge, the current study is the first to show that berberine suppresses CPT-11-induced $\mathrm{NF}-\kappa \mathrm{B}$ activation in a dose-dependent manner in HCT116 cells. The results of the SRB assay, Hoechst 33258 and Annexin V/PI staining demonstrated that berberine potentiates CPT-11-induced apoptosis. Compared with previous methods, including the aformentioned methods, berberine is a simple, available and applicable means to increase CPT-11-induced apoptosis. The safety of berberine in humans has already been established and it is widely used as a therapeutic drug for the treatment of intestinal infections and diarrhea.

$\mathrm{NF}-\kappa \mathrm{B}-$ mediated antiapoptosis is essentially dependent on the ability of $\mathrm{NF}-\kappa \mathrm{B}$ to enhance transcription of target genes $(22,23)$, including c-IAP1, c-IAP2, survivin and Bcl-xL, which prevents tumor cell killing effects (22-24). Thus, in the present study, western blotting was used to detect the effect of berberine on expression levels of these antiapoptotic proteins. The results demonstrate that berberine abolished CPT-11-induced expression of c-IAP1, c-IAP2, survivin and Bcl-xL (Fig. 5). Therefore, berberine may potentiate CPT-11-induced apoptosis by downregulating the NF- $\kappa \mathrm{B}$ antiapoptotic target genes.

Myelosuppression and diarrhea are the two major toxicities associated with CPT-11 treatment and numerous studies have investigated pharmacological modulation to reduce CPT-11 toxicity. In the current study, concentrations between 2.5 and $10 \mu \mathrm{M}$ berberine were non-toxic for HCT116 cells while still enhancing chemosensitivity to CPT-11. Therefore, CPT-11-induced toxicity may be alleviated by berberine treatment, thus, potentiating anticancer effects with lower doses of CPT-11. These results are consistent with those in previous studies, indicating that berberine is a non-toxic chemoadjuvant that sensitizes tumor cells to CPT-11 by inhibiting NF- $\kappa$ B. Future studies are likely to include in vivo studies to reduce CPT-11 toxicity using berberine as a chemoadjuvant to CPT-11.

By investiagting the mechanism of interplay between berberine, NF- $\mathrm{KB}$ and the cytotoxicity of CPT-11, the present study provides a basis for the rational choice of natural compounds, including berberine, in chemotherapy. In addition, the importance of basic cell biology in developing an integrated approach to pharmacological intervention is highlighted. The current study also indicates the possibility that natural compounds, which inhibit NF- $\mathrm{B}$ activation, may be used to augment the cytotoxicity of chemotherapeutic agents.

\section{Acknowledgements}

This study was supported by grants from the China Postdoctoral Science Foundation (grant no. 20090461139), the National Natural Science Foundation of China (grant no. 81001457) and the Natural Science Foundation of the Provincial Education Department of Anhui (grant no. KJ2008A167).

\section{References}

1. Sarkar FH and Li Y: Harnessing the fruits of nature for the development of multi-targeted cancer therapeutics. Cancer Treat Rev 35: 597-607, 2009.

2. Li F and Sethi G: Targeting transcription factor NF-kappaB to overcome chemoresistance and radioresistance in cancer therapy. Biochim Biophys Acta 1805: 167-180, 2010.

3. Van Antwerp DJ, Martin SJ, Kafri T, Green DR and Verma IM: Suppression of TNF-alpha-induced apoptosis by NF-kappaB. Science 274: 787-789, 1996

4. Cusack JC Jr, Liu R and Baldwin AS Jr: Inducible chemoresistance to 7-ethyl-10-[4-(1-piperidino)-1-piperidino] -carbonyloxycamptothecin (CPT-11) in colorectal cancer cells and a xenograft model is overcome by inhibition of nuclear factor-kappaB activation. Cancer Res 60: 2323-2330, 2000.

5. Baldwin AS Jr: Series introduction: the transcription factor NF-kappaB and human disease. J Clin Investig 107: 3-6, 2001.

6. Wang CY, Mayo MW, Korneluk RG, Goeddel DV and Baldwin AS Jr: NF-kappaB antiapoptosis: induction of TRAF1 and TRAF2 and c-IAP1 and c-IAP2 to suppress caspase- 8 activation. Science 281: 1680-1683, 1998.

7. $\mathrm{Xu} \mathrm{Y}$ and Villalona-Calero MA: Irinotecan: mechanism of tumor resistance and novel strategies for modulating its activity. Ann Oncol 13: 1841-1851, 2002.

8. Wasserman E, Sutherland W and Cvitkovic E: Irinotecan plus oxaliplatin: a promising combination for advanced colorectal cancer. Clin Colorectal Cancer 1: 149-153, 2001.

9. Stahel RA and Zangemeister-Wittke U: Antisense oligonucleotides for cancer therapy-an overview. Lung Cancer 41 (Suppl 1): S81-S88, 2003.

10. Shah SA, Potter MW, McDade TP, Ricciardi R, Perugini RA, Elliott PJ, Adams J and Callery MP: 26S proteasome inhibition induces apoptosis and limits growth of human pancreatic cancer. J Cell Biochem 82: 110-122, 2001.

11. Cusack JC Jr, Liu R, Houston M, Abendroth K, Elliott PJ, Adams $\mathrm{J}$ and Baldwin AS Jr: Enhanced chemosensitivity to CPT-11 with proteasome inhibitor PS-341: implications for systemic nuclear factor-kappaB inhibition. Cancer Res 61: 3535-3540, 2001.

12. Guo J, Verma UN, Gaynor RB, Frenkel EP and Becerra CR: Enhanced chemosensitivity to irinotecan by RNA interference-mediated down-regulation of the nuclear factor-kappaB p65 subunit. Clin Cancer Res 10: 3333-3341, 2004.

13. Lagdec P, Griessinger E, Nawrot MP, Fenouille N, Colosetti P, Imbert V, Mari M, Hofman P, Czerucka D, Rousseau D, et al: Pharmacological targeting of NF-kappaB potentiates the effect of the topoisomerase inhibitor CPT-11 on colon cancer cells. Br J Cancer 98: 335-344, 2008.

14. Liu S, Fang Y, Shen H, Xu W and Li H: Berberine sensitizes ovarian cancer cells to cisplatin through miR-21/PDCD4 axis. Acta Biochim Biophys Sin (Shanghai) 45: 756-762, 2013.

15. Pandey MK, Sung B, Kunnumakkara AB, Sethi G, Chaturvedi MM and Aggarwal BB: Berberine modifies cysteine 179 of IkappaBalpha kinase, suppresses nuclear factor-kappaB-regulated antiapoptotic gene products, and potentiates apoptosis. Cancer Res 68: 5370-5379, 2008. 
16. Papazisis KT, Geromichalos GD, Dimitriadis KA and Kortsaris AH: Optimization of the sulforhodamine B colorimetric assay. J Immumol Methods 208: 151-158, 1997.

17. Hussain AR, Ahmed SO, Ahmed M, Khan OS, Al Abdulmohsen S, Platanias LC, Al-Kuraya KS and Uddin S: Cross-Talk between NF- $\kappa$ B and the PI3-Kinase/AKT pathway can be targeted in primary effusion lymphoma (PEL) cell lines for efficient apoptosis. PLoS One 7: e39945, 2012.

18. Hussain AR, Ahmed M, Al-Jomah NA, Khan AS, Manogaran P, Sultana M, Abubaker J, Platanias LC, Al-Kuraya KS and Uddin S: Curcumin suppresses constitutive activation of nuclear factor-kappa $\mathrm{B}$ and requires functional Bax to induce apoptosis in Burkitt's lymphoma cell lines. Mol Cancer Ther 7: 3318-3329, 2008.

19. Wang Q, Zhang J, Liu L, Sharma S and Dong Q: Quercetin potentiates doxorubicin mediated antitumor effects against liver cancer through p53/Bcl-xl. PLoS One 7: e51764, 2012.
20. Zou Z, Xie L, Wei J, Yu L, Qian X, Chen J, Wang T and Liu B: Synergistic anti-proliferative effects of gambogic acid with docetaxel in gastrointestinal cancer cell lines. BMC Complement Altern Med 12: 58, 2012.

21. Kawano Y, Nagata M, Kohno T, Ichimiya A, Iwakiri T, Okumura $\mathrm{M}$ and Arimori K: Caffeine increases the antitumor effect of Cisplatin in human hepatocellular carcinoma cells. Biol Pharm Bull 35: 400-407, 2012.

22. Pacifico F and Leonardi A: Role of NF-kappaB in thyroid cancer. Mol Cell Endocrinol 321: 29-35, 2010.

23. Baud V and Karin M: Is NF-kappaB a good target for cancer therapy? Hopes and pitfalls. Nat Rev Drug Discov 8: 33-40, 2009.

24. Kuoharczak J, Simmons MJ, Fan Y and Gélinas C: To be, or not to be: NF-kappaB is the answer - role of Rel/NF-kappaB in the regulation of apoptosis. Oncogene 22: 8961-8982, 2003. 